\title{
Wellbeing Effect of Social Media Postings Analysis Using Rasch Models
}

\author{
Z Ardi ${ }^{1}$, I Sukmawati ${ }^{2}$, I Ifdil ${ }^{3}$ \\ Department of Guidance and Counseling, Universitas Negeri Padang, Indonesia ${ }^{1,2,3}$ \\ \{zadrian@fip.unp.ac.id $\left.{ }^{1}\right\}$
}

\begin{abstract}
Social media usage is a highly developed research in the last decade. This media impact is positively related to the marketing process, communication, politics, news and the other latest information. However, the sharing of personal life, feelings or problems will affect the state of mental health (wellbeing). This study examined the effect of social media use to the condition of psychological wellbeing after the activity was performed. The research data was collected using ZSAI inventory (Zadrian Social-Media Addiction Inventory) with the sample consists of 326 people. Data analysis was performed by using Rasch model analysis. The analysis on the research results shows that there is a significant relationship between the usages of social media with the condition of individual subjective well-being. The users feels more comfortable and happy when the content that they shares through social media gets positive responses from others, feeling "empty" if cannot access social media in period of time, the needs to express personal feelings/problems on social media. Nevertheless, the social media users tend to feel addicted and lost productivity by using it.
\end{abstract}

Keywords: Social media, Wellbeing, Rasch Analysis, Addiction

\section{Introduction}

Communication through technology has created new phenomena in the world of psychology and communication. One technology with significant impact is the internet [1]-[4]. The existence of the Internet indirectly gave birth to a new generation of digital, also called Generation Ne (xt) or Digital Generation [5].

The Internet comes by offering a variety of conveniences in communications and improvised connections over time. The ease of sharing content and data has been very easy in the last decade [6], [7]. Based on Internet World Stats data in 2012 it was found that active internet users in the world are 2,405,518,376 people which in this case represents a significant increase of $544 \%$ when compared to 2000 [2], [3], [8]. When reviewed the data, within a month some of the accessed internet content comes from Facebook, Youtube, Google+, Twiter and LinkedIn [3].

Based on the study of internet users of the world, the use of the internet in the past few years focused more on the use of social media. This is evidenced by $86 \%$ of internet users in the United States and $79 \%$ of users coming from Europe are active social media users, while in Indonesia alone from 63 million active internet users, $95 \%$ of them are active social media users [7], [8]. The exposure of these statistics corroborates the evidence that the internet is a new 
medium in the process of communication and socialization conducted by the community. Most Internet users take advantage of social media as a means to connect with colleagues, family and so forth.

Social media that developed rapidly serve as a medium to present themselves and connect with other users by carrying different concepts. Recent studies suggest that social media serve as a medium for sharing personal information, personal life, knowledge, professional life / work, etc. [3]. In addition, through social media, users can also get certain psychic support related to their condition [1], [3], [9]. This happens when the user uploads his / her condition (on many social media platforms also called post / post process) through social media and is responded by other users and anonymously. However, it is not uncommon to find misconduct in social media, such as unauthorized disclosure of information (such as uploading pornographic content, sadism, etc.), cyber bullying, internet addiction, risky behaviors and contact with hazardous communities [10].

If viewed from the user, social media is mostly used by people with productive ages [11]. Social media is widely used by the young generation, which in this study focuses on students in interacting with their environment. Having an account in social media is a common practice for students [12] and is generally used to present themselves, socialize, communicate and the like.

Access to social media from the younger generation in general make this activity as a means to express the condition of self, expression and other similar things [13]-[15]. Even some of these activities are related to individual mental health conditions, such as mood changes, individual motivations and perceptions. High social media usage activities can also trigger individuals experiencing dependence and disruption in everyday life [16]-[18].

This article discusses the effects of using social media for individuals on the well being condition, and then viewed from the gender and domicile. The next condition that discussed is the tendency of addiction and psychological effects that can be generated from the use of social media.

\section{Method}

The population of this study comes from all students of Universitas Negeri Padang consists of eight faculties. Samples were taken taking by the group of each faculty which consist of 326 people. In general, the demographics of the study sample consisted of $62.27 \%$ women and $37.73 \%$ of men, $45 \%$ from rural areas, $26.38 \%$ of small towns, $15.03 \%$ of cities, and $13.50 \%$ of the capitals. The research data were collected using ZSAI inventory (Zadrian Social-Media Addiction Inventory) with Alpha Crobach 0.91. ZSAI items were scored by using Likert scale type in range of 1 to 5 points. The data of this study was processing by using Rasch Models Analysis and Winstep version 3.73. Differences in the use of social media related to individual wellbeing are described using inferential statistics using student-t and Pearson Correlation.

\section{Result and Discussion}

Demographic analysis and social media usage conditions are needed for holistic user interpretation. Based on the data, there are the frequency conditions of respondents in accessing social media based on Table 1. 
Table 1 Frequency of accessing social media and posting in a day

\begin{tabular}{cccc}
\hline \multirow{5}{*}{ Duration } & & Men & Women \\
\hline \multirow{5}{*}{ Post/Day } & $\leq 1$ hour & $13.01 \%$ & $4.93 \%$ \\
\cline { 2 - 4 } & $2-4$ hour & $28.46 \%$ & $31.53 \%$ \\
\cline { 2 - 4 } & $5-7$ hour & $33.33 \%$ & $40.89 \%$ \\
\cline { 2 - 4 } & $8-11$ hour & $16.26 \%$ & $14.78 \%$ \\
\cline { 2 - 4 } & $\geq 12$ hour & $8.94 \%$ & $7.88 \%$ \\
\cline { 2 - 4 } & Never & $29.27 \%$ & $11.82 \%$ \\
\cline { 2 - 4 } & Once & $43.90 \%$ & $53.20 \%$ \\
\cline { 2 - 4 } & $2-3$ times & $22.76 \%$ & $30.05 \%$ \\
\cline { 2 - 4 } & $\mathbf{2}$ - times & $3.25 \%$ & $4.93 \%$ \\
\hline
\end{tabular}

Table 1 shows that women generally spend more time using social media more than five hours a day, and more than half (58.20\%) share content in the form of posting on social media at least once a day. While the more dominant males have duration in accessing social media under 4 hours in a day and generally do posting once a day. The data shows that the duration of frequency is related to the number of post on social media every day; the higher the duration of access each day will increase the number of posts.

The high duration of social media access becomes one of the indicators of the psychological effects that can be caused afterwards [19]-[21], which effect can be in the form of addiction [22], [23]. In detail, the effects on social media post are presented in Table 2.

The most obvious effect given by social media activity is the presence of happiness when there is a positive response to the shared content (item 5) with a logits value of -1.38 , which means that respondents generally "feel good" about other users' responses to their content. Another condition that needs to be considered is the feeling of "emptiness" if in some time the user cannot access the social media (item 2) thus affecting the condition of wellbeing. The same thing happens when an individual receives a negative reply to the content that they share on social media.

Table 2 Activities in Social Media Relating to the Individuals Wellbeing Conditions

\begin{tabular}{lcc}
\hline \multicolumn{1}{c}{ Item } & $\begin{array}{c}\text { Total } \\
\text { Score }\end{array}$ & $\begin{array}{c}\text { Item } \\
\text { Measure } \\
\text { (Logits) }\end{array}$ \\
\hline $\begin{array}{l}\text { Feel uncomfortable when cannot } \\
\text { update a post (i-4) }\end{array}$ & 604 & .90 \\
\hline $\begin{array}{l}\text { The desire to always look perfect } \\
\text { on social media (i-1) }\end{array}$ & 681 & .47 \\
\hline $\begin{array}{l}\text { More comfortable sharing personal } \\
\text { feelings/problems in social media } \\
\text { (i3) }\end{array}$ & 703 & .36 \\
\hline $\begin{array}{l}\text { Upset if disturbed while accessing } \\
\text { social media (i-7) }\end{array}$ & 695 & .33 \\
\hline $\begin{array}{l}\text { Life feels "empty" if not access } \\
\text { social media (i-2) }\end{array}$ & 836 & -.32 \\
\hline $\begin{array}{l}\text { Disrupted when receiving negative } \\
\text { comments on social media (i-6) }\end{array}$ & 843 & -.37 \\
\hline Feel happy when getting a lot of & 1063 & -1.38 \\
\hline
\end{tabular}


When seen from gender differences in social media usage activities related to wellbeing conditions are presented in Graph 2, there are variations in social media usage activity seen from gender, in some aspects men are more likely to have high activity, as well as women.

A very significant condition is seen in the feeling of happiness if the content shared has many positive responses, and this is more likely to be experienced by women, which is women in logits (-1.54) and men with logits (measure) -1.54. However, both men and women find it difficult to feel uncomfortable if they cannot share content through social media. The same thing also happened when receiving negative comments on social media, where both men and women would like to feel uncomfortable with it. On the contrary, contrasting results are shown in behavior to share the personal feelings/problems through social media which is more likely to be performed by women than men.

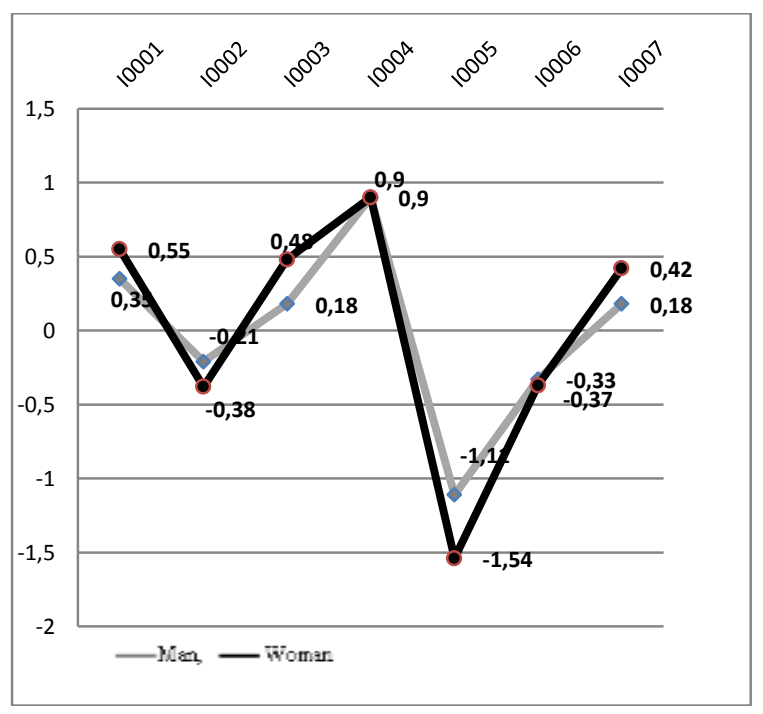

Graph 1 The Differential Item Functioning (DIF) of the use of social media related to wellbeing condition based on Gender

The subsequent analysis was conducted on the wellbeing conditions of individuals that related to activities in social media based on their domicile [24]-[27]. The significant difference in the use of social media that affects the wellbeing conditions of an individual is at expressing the personal feelings/problems through social media and feelings of happiness when the content being shared gets a "like" response. In general, individual wellbeing conditions that are influenced by activities in social media vary, both in terms of gender and from user domicile.

Users who come from cities tend to be reluctant to express the personal feelings openly through social media when compared to users of other domiciles. Another striking condition lies in the feeling of happiness after getting a positive response from content shared on social media, which the users who live in the rural area/village are happier than others. Distribution of wellbeing conditions in relation to activity in terms of domicile can provide a general overview of the distribution of social media users' demographics and their relation to psychological effects [28], [29]. The continued effect on wellbeing conditions from those obtained from this analysis 
is with regard to the contribution of content shared on social media to users based on their domicile clusters [24], [28], [30].

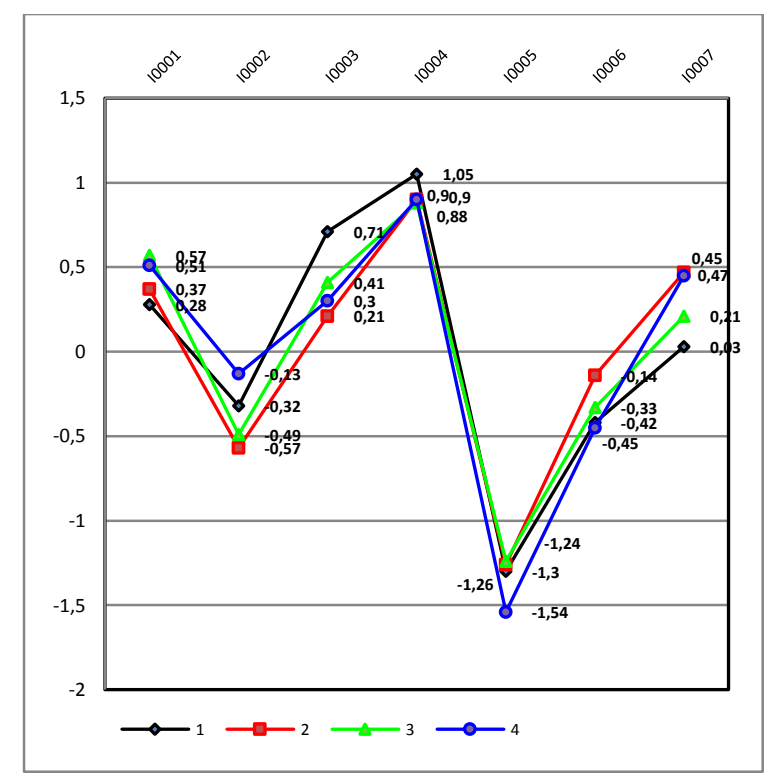

*1=Metropolis, 2=City, 3=Town, 4=Rural/Village

Graph 2 The Differential Item Functioning (DIF) of the use of social media related to wellbeing condition based on Domicile

The strong condition of variability and the distribution of individual wellbeing conditions in activity in social media are also evidenced by testing the mean differences in Table 5.

Table 3 Differences in well conditions of social media activity based on Domicile

\begin{tabular}{cccccc}
\hline Analysis & $\mathrm{F}$ & $\mathrm{Sig}$ & $\mathrm{t}$ & $\mathrm{df}$ & $\mathrm{Sig}$ \\
\hline $\begin{array}{l}\text { wellbeing } \\
\text { condition }\end{array}$ & 7.432 & .007 & .921 & 231 & .358 \\
\hline
\end{tabular}

\subsection{The Tendency of Social Media Addiction}

The high liveliness of respondents in using social media is then used as an assumption to see the contribution of their use to the well-being condition of the respondents [25], [31]-[33]. Table 4 shows that the significant relationship between social media use behavior and the well-being condition of the respondents after the activity.

Table 4 contributions of social media posting with individual subjective well being condition

\begin{tabular}{lll}
\hline Analysis & $\mathrm{r}$ & Sig. \\
\hline
\end{tabular}




Pearson Correlation $\quad .577 \quad .000$

A significant relationship between the level of activity of social media usage and the individual wellbeing condition is one of the key factors. Changes in self-atmosphere such as happiness, emotional control, self-disclosure, and mood are some important things to note due to the use of social media [26], [28], [31]. This is reinforced with the fact that the duration of social media usage by the respondents is high. There are strongly predicted that there is a tendency to use social media in order to maintain mood, the need to share, the need to hear, the need of self actualization of social media users.

One of the important aspects of this diagnosis is the fact that the "emptiness/hollow" condition that the user can experience if they cannot access social media for a certain period of time. This fact is an important indicator in classifying individuals has experienced addiction conditions [27], [34]. Other conditions are individuals who cannot accept comments or unexpected responses that may affect the user's mood.

The tendency and diagnosis of addiction is an important key to studying the contribution of social media use to individual wellbeing [27], [35]. The further effects that can be caused by the use of social media, especially excessive use can be the focus of other findings.

\section{Conclusion}

The analysis of the research results shows that there is a significant relationship between social media use behavior with the condition of individual subjective well-being. Individuals tend to feel more comfortable and happy if the post or content that he shares through social media get many responses from other users. This suggests that there is a need to be recognized and noticed through social media. The right proportion in the use of social media will make this activity one of the tension-releasing activities in everyday life, but excessive activity (the duration of access time is too long) will make individuals within the category of addiction [36] [38].

There is considerable variability in the use of social media that related to wellbeing conditions when viewed from gender and domicile. The dominant diversity is related to the desire express the personal feelings in social media and mood conditions that could disrupted if the users cannot access social media.

The diagnosis of addiction can be known through an analysis of the behavior of social media access in depth. This is evidenced by the condition of individual dependence on social media in improving the mood, the need to express the personal feelings and the need to self-actualization. In-depth attention and analysis are needed to see in what extent the use of social media can be categorized as addictive and interfere with the user's daily effective conditions. Psychotherapy and counseling services are also needed for users who are indicated to be addicted [39].

\section{References}

[1] I. A. Zolkepli and Y. Kamarulzaman, "Social media adoption: The role of media needs and innovation characteristics," Comput. Human Behav., vol. 43, pp. 189-209, Feb. 2015.

[2] M. E. Mitchell, J. R. Lebow, R. Uribe, H. Grathouse, and W. Shoger, "Internet use, happiness, social support and introversion: A more fine grained analysis of person variables and internet activity," Comput. Human Behav., vol. 27, no. 5, pp. 1857-1861, 
Sep. 2011.

[3] S. Oh and S. Y. Syn, "Motivations for sharing information and social support in social media: A comparative analysis of Facebook, Twitter, Delicious, \{YouTube\}, and Flickr," J. Assoc. Inf. Sci. Technol., vol. 66, no. 10, pp. 2045-2060, Apr. 2015.

[4] S. Y. Tettegah, "Foreword," in Emotions, Technology, and Social Media, Elsevier, 2016, pp. xi--xiv.

[5] P. Q. Ayun, "Fenomena Remaja Menggunakan Media Sosial dalam Membentuk Identitas," \{CHANNEL\} J. Komun., vol. 3, no. 2, Oct. 2015.

[6] R. N. Emilia, W. Abdillah, and Abdullah, "Pengaruh partisipasi dalam anggaran dan kejelasan sasaran anggaran serta peran manajerial pengelolaan keuangan daerah terhadap kinerja pemerintah daerah (Studi empiris pada pemerintah provinsi Bengkulu)," J. Fairness, vol. 3, no. 3, pp. 42-53, 2013.

[7] N. Anasari, "MEDIA SOSIAL SEBAGAI PANGGUNG DRAMA (Studi Deskriptif Presentasi Diri Pengguna Twitter di Kalangan Mahasiswa Unesa)," Paradigma, vol. 3, no. 3, 2015.

[8] S. Brooks, "Does personal social media usage affect efficiency and well-being?," Comput. Human Behav., vol. 46, pp. 26-37, May 2015.

[9] N. Koteyko and D. Hunt, "Performing health identities on social media: An online observation of Facebook profiles," Discourse, Context $\{\&\}$ Media, vol. 12, pp. 59-67, Jun. 2016.

[10] S. Valenzuela, N. Park, and K. F. Kee, "Is There Social Capital in a Social Network Site?: Facebook Use and College Students\{ltextquotesingle\} Life Satisfaction, Trust, and Participation," J. Comput. Commun., vol. 14, no. 4, pp. 875-901, Jul. 2009.

[11] I. Andarwati, "Citra Diri Ditinjau Dari Intensitas Penggunaan Media Jejaring Sosial Instagram Pada Siswa Kelas XI SMA N 9 Yogyakarta," J. Ris. Mhs. Bimbing. Dan Konseling, vol. 5, no. 3, 2016.

[12] E. A. Sosiawan, "Penggunaan situs jejaring sosial sebagai media interaksi dan komunikasi di kalangan mahasiswa," J. Ilmu Komun. Terakreditasi, vol. 9, no. 1, pp. 60-75, 2011.

[13] E. Orehek and L. J. Human, "Self-Expression on Social Media," Personal. Soc. Psychol. Bull., vol. 43, no. 1, pp. 60-70, Dec. 2016.

[14] J. Herzig, G. Feigenblat, M. Shmueli-Scheuer, D. Konopnicki, and A. Rafaeli, "Predicting Customer Satisfaction in Customer Support Conversations in Social Media Using Affective Features," in Proceedings of the 2016 Conference on User Modeling Adaptation and Personalization - \{UMAP\} Ntextquotesingle\}16, 2016.

[15] L. de Vries, A. M. Peluso, S. Romani, P. S. H. Leeflang, and A. Marcati, "Explaining consumer brand-related activities on social media: An investigation of the different roles of self-expression and socializing motivations," Comput. Human Behav., vol. 75, pp. 272-282, Oct. 2017.

[16] M. Matthews et al., "The double-edged sword: A mixed methods study of the interplay between bipolar disorder and technology use," Comput. Human Behav., vol. 75, pp. 288-300, Oct. 2017.

[17] K. S. Rook and S. T. Charles, "Close social ties and health in later life: Strengths and vulnerabilities.," Am. Psychol., vol. 72, no. 6, pp. 567-577, Sep. 2017.

[18] L. Zhan, Y. Sun, N. Wang, and X. Zhang, "Understanding the influence of social media on people's life satisfaction through two competing explanatory mechanisms," Aslib J. Inf. Manag., vol. 68, no. 3, pp. 347-361, May 2016.

[19] N. N. Capriola-Hall, A. T. Wieckowski, T. H. Ollendick, and S. W. White, "The 
Influence of Social Communication Impairments on Gaze in Adolescents with Social Anxiety Disorder," Child Psychiatry \{\&\} Hum. Dev., vol. 49, no. 4, pp. 672-679, Jan. 2018.

[20] N. H. T. Lam, J. T.-H. Tsiang, and B. K. P. Woo, "Exploring the Role of \{YouTube\} in Disseminating Psychoeducation," Acad. Psychiatry, vol. 41, no. 6, pp. 819-822, Oct. 2017.

[21] A. M. Mínguez, "The Role of Family Policy in Explaining the International Variation in Child Subjective Well-Being," Soc. Indic. Res., vol. 134, no. 3, pp. 1173-1194, Dec. 2017.

[22] D. Blackwell, C. Leaman, R. Tramposch, C. Osborne, and M. Liss, "Extraversion, neuroticism, attachment style and fear of missing out as predictors of social media use and addiction," Pers. Individ. Dif., vol. 116, pp. 69-72, Oct. 2017.

[23] C.-Y. Lin, A. Broström, P. Nilsen, M. D. Griffiths, and A. H. Pakpour, "Psychometric validation of the Persian Bergen Social Media Addiction Scale using classic test theory and Rasch models," J. Behav. Addict., vol. 6, no. 4, pp. 620-629, Dec. 2017.

[24] Y. Asher, A. Stark, and G. D. Fireman, "Comparing electronic and traditional bullying in embarrassment and exclusion scenarios," Comput. Human Behav., vol. 76, pp. 2634, Nov. 2017.

[25] T. Hatchel, S. Negriff, and K. Subrahmanyam, "The relation between media multitasking, intensity of use, and well-being in a sample of ethnically diverse emerging adults," Comput. Human Behav., vol. 81, pp. 115-123, Apr. 2018.

[26] Z. Ouyang, Y. Wang, and H. Yu, "Internet Use in Young Adult Males: from the Perspective of Pursuing Well-Being," Curr. Psychol., vol. 36, no. 4, pp. 840-848, Jun. 2016.

[27] H. M. Rus and J. Tiemensma, "Social Media under the Skin: Facebook Use after Acute Stress Impairs Cortisol Recovery,” Front. Psychol., vol. 8, Sep. 2017.

[28] E. Ercag and M. Tezer, "The Effect of Social Media Use on the Academic Success and Attitude of Students," Ponte Int. Sci. Res. J., vol. 73, no. 7, 2017.

[29] C.-H. Jin, "The Role of Media Usage on Building Social Capital: Multiculturalism in Korea Case," African Asian Stud., vol. 16, no. 3, pp. 215-242, Sep. 2017.

[30] R. G. Duffett, "Influence of social media marketing communications on young consumers' attitudes," Young Consum., vol. 18, no. 1, pp. 19-39, Apr. 2017.

[31] S. Eleuteri, V. Saladino, and V. Verrastro, "Identity, relationships, sexuality, and risky behaviors of adolescents in the context of social media," Sex. Relatsh. Ther., vol. 32, no. 3-4, pp. 354-365, Oct. 2017.

[32] J.-S. Lin, Y.-I. Lee, Y. Jin, and B. Gilbreath, "Personality Traits, Motivations, and Emotional Consequences of Social Media Usage," Cyberpsychology, Behav. Soc. Netw., vol. 20, no. 10, pp. 615-623, Oct. 2017.

[33] D. Liu and W. K. Campbell, "The Big Five personality traits, Big Two metatraits and social media: A meta-analysis," J. Res. Pers., vol. 70, pp. 229-240, Oct. 2017.

[34] F. M. Schneider, B. Zwillich, M. J. Bindl, F. R. Hopp, S. Reich, and P. Vorderer, "Social media ostracism: The effects of being excluded online," Comput. Human Behav., vol. 73, pp. 385-393, Aug. 2017.

[35] L. E. Annisette and K. D. Lafreniere, "Social media, texting, and personality: A test of the shallowing hypothesis," Pers. Individ. Dif., vol. 115, pp. 154-158, Sep. 2017.

[36] E. K. Erevik, S. Pallesen, C. S. Andreassen, Ø. Vedaa, and T. Torsheim, "Who is watching user-generated alcohol posts on social media?," Addict. Behav., vol. 78, pp. 131-137, Mar. 2018. 
[37] M. R. Hasan, A. K. Jha, and Y. Liu, "Excessive use of online video streaming services: Impact of recommender system use, psychological factors, and motives," Comput. Human Behav., vol. 80, pp. 220-228, Mar. 2018.

[38] J. Spilková, P. Chomynová, and L. Csémy, "Predictors of excessive use of social media and excessive online gaming in Czech teenagers," J. Behav. Addict., vol. 6, no. 4, pp. 611-619, Dec. 2017.

[39] Z. Ardi and F. M. Yendi, "Students Attitude Towards LGBTQ; the Future Counselor Challenges," J. Konseling dan Pendidik., vol. 5, no. 2, p. 74, Jun. 2017. 